\section{A new medical research institute}

Because most of the glamour of recent nutrition research has gone to those companies and individuals uncovering the genes related to girth, one important piece of news has been overlooked by both the press and nutrition researchers. But that will soon change. Early last month, the creation of a new international medical research and educa-

\section{Feeding frenzy at HGS's table}

When Smithkline Beecham bankrolled the efforts of Human Genome Sciences, Inc. (HCS) in Rockville, Maryland, to identify human genes of potential therapeutic interest, the Philadelphia drug company counted on a substantial return on its investment. Three years later, HGS computers have spit out more than even a giant like Smithkline could hope to chew. Thus HCS and SmithKline have "invited" others to the feast, offering them access to the database and accompa-

nying techniques in return for a substantial investment and a promise to share any profit that results.

In a 2 July press conference, William Haseltine, chairman and chief executive officer of HCS, and J.P. Garnier, chief operating officer and president of Pharmaceuticals and Consumer Healthcare for SmithKline, announced that they had signed "genomics collaboration and license agreements" with Schering-Plough Corporation, headquartered in Madison, New Jersey, and French pharmaceutical giant Synthelabo. The two new companies will pay a total of US\$90 million in return for access to the HGS information.

This is not the first time HCS and SmithKline have opened the doors to other companies, and it will not be the last. Last June, Japanese pharmaceutical giant Takeda Chemical Industries, Ltd., entered a similar agreement, and another agreement is pending with the German company Merck KGaA in Darmstadt. At the July press conference, Haseltine said that "all parties have agreed there is room for at least one more [company]," suggesting that the current frenzy isn't over. tion institute - and one that could eventually rival the Howard Hughes Medical Institute in scope - was announced, along with plans to focus initially on nutrition-related research. Both the new Van Andel Institute (logo shown) and the Van Andel Molecular and Genetic Nutrition Research Program will be located in Grand Rapids, Michigan, near the home of the founders of the Institute, Jay and Betty Van Andel. A great deal of money (although the exact amount is unknown) is targeted to the new program, and a great deal more will eventually be handled by the institute.

Jay Van Andel is co-owner of AmWay Corporation, a multibillion-dollar company that sells a wide range of household goods through an international network of more than two million independent contractors. His financial assets have been estimated at more than US $\$ 4.3$ billion, making him the seventh wealthiest person in the United States. Although officials at the Van Andel Institute will not say how much the institute may eventually have, scientists involved in developing the Institute over the last few years say it may total several billion dollars.

Unlike the Howard Hughes Medical Institute, the Van Andel Institute plans to set up independent medical research centers to concentrate on "neglected" or "high-risk" areas of medical research, a model similar to that of the J. David Gladstone Institute at the University of California in San Francisco.

Retired cardiac surgeon Luis A. Tomatis

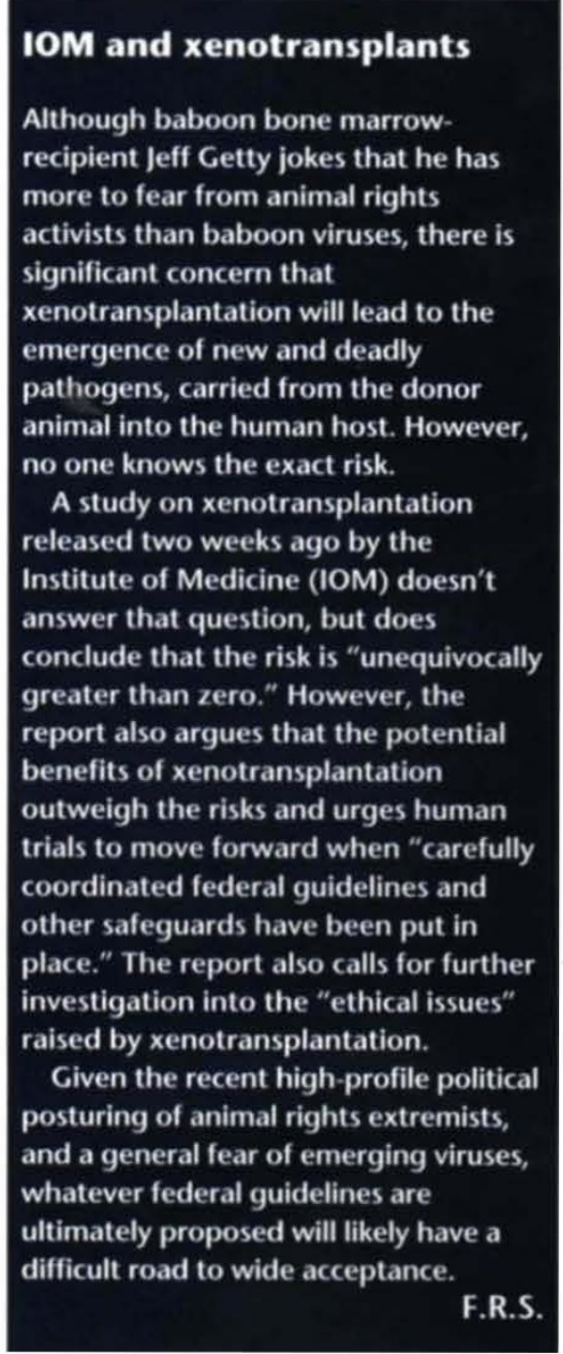

is the president and chief operating officer of the new institute. A director for the new nutrition institute should be announced within the next few weeks.

Fintan R. Steele

\section{Kan pushes the pill in Japan}

Naoto Kan, Japan's new reform-minded Minister of Health, says a low-dose form of "the pill" could become available in Japan next year, 30 years after oral contraceptives first became available in other countries.

The debate over the pill resurfaced last year (see Nature Medicine 1,$1115 ; 1995)$ following the completion of a three-year study by the ministry's Central Pharmaceutical Affairs Council that looked for links between use of the pill and HIV spread in other countries. No link was found in the United States and Europe.

Officials at the ministry - which has been considering approving the pill for years - are still debating the issue, but a decision may finally be forced next year according to Kan. A former civic activist, Kan has been creating waves at the ministry since his appointment in January and is growing in popularity in Japan for his uncommonly outspoken remarks. He was instrumental in the recent compensation settlement for hundreds of Japanese hemophiliacs infected with HIV through blood products, saying that Napoleon may have had no word for "no" in his vocabulary, but Japanese bureaucrats have no word for "mistake" in theirs.

RICHARD NATHAN Tokyo, Japan 